\title{
Effects of retention interval activity on short-term memory in retardates
}

ROLLAND METZGER, DIXON STATE SCHOOL SEYMORE SIMON AND RAYMOND DITRICHS, NORTHERN ILLINOIS UNIVERSITY

\begin{abstract}
Seventy retarded Ss showed reductions in the shortterm retention of single verbal items to $73 \%$ correct recall in 16 sec. under conditions where words different from the stimulus word filled the retention interval. Under retention interval conditions of no instructed activity, instructed rehearsal, and music listening, negligible declines in recall were observed.
\end{abstract}

\section{Problem}

In selecting retention interval activities in studies of short-term memory, E's have generally assumed that the activities selected both prevent rehearsal of the material to be recalled and do not interfere with the retention of these materials. However, empirical evidence suggests that, in addition to rehearsal confoundings, the experimental designs employed in shortterm memory studies do in fact define retroactive as well as proactive interference paradigms (Keppel, 1965; Postman, 1964).

The purpose of the present study was to examine the effects of different retention interval activities on the short-term memory of single verbal items by retardate Ss. Specific attention was directed to the question of whether the retention interval function obtained under conditions of instructed rehearsal would differ from those obtained under other retention interval conditions.

\section{Method}

The Ss were 70 institutionalized retardates, 29 males and 41 females, from Dixon State School. Chronological ages ranged from 16 to $40(\mathrm{M}=27 \mathrm{yr}$.) and IQ's ranged from 50 to $70(M=58.2)$.

The Ss were assigned at random to one of seven groups. Each of these groups was distinguished from the other by the retention interval activity which occurred between presentation of the stimulus word and the signal to recall the stimulus word. These activities were as follows: (1) Blank-Ss received no auditory stimulation nor were they given any task to perform during the intervals. (2) Rehearsal-Ss were instructed to rehearse the word to themselves during the intervals. (3) Color naming-Ss were requested to name colors from a chart before them. Seven different colors were used on the chart. (4) Color hearing-Ss heard names of colors which were prerecorded on tape. The colors employed were the same as those used in color naming. (5) Redundant word hearing-Ss heard prerecorded words. Seven different words were used so as to be equivalent in number to the color hearing condition. (6) Different word hearing-in contrast to the redundant word hearing condition, all words employed in the retention interval differed from every other word used in a retention interval. Stimulus words were never presented as retention interval items. (7) Ss heard prerecorded vocal selections of popular music.

The stimulus words and retention interval words were common nouns taken from the first 2000 words of the Gates list (1935)。

Following instructions, Ss were given two practice trials to familiarize them with the task. Test trial words were then presented followed by time intervals of either $0,2,4,8$, or $16 \mathrm{sec}$. during which time $\mathrm{S}$ heard or performed the activity to which he was assigned. The design was thus a repeated measurements design with retention interval activities as the between Ss variable, and retention intervals as the within Ss variable. At the end of each retention interval a $750 \mathrm{cps}$ tone was sounded as a signal for $\mathrm{S}$ to recall the stimulus word. Eight sec. following this tone S was told "time's up." Three sec. after the "time's up" signal a new stimulus word was presented.

The tape heard by any S contained 50 single words as stimuli. Ten words were assigned to each of the five retention intervals employed. The 50 words were divided into 10 sequences of five consecutive words. Each sequence contained all five retention intervals. Within each sequence, time intervals were counterbalanced across Ss so that each word occurred equally often at each time interval. The stimulus words as well as their order of presentation were identical for all Ss. Words and names of colors were presented during the retention intervals at a rate of approximately 1 per sec.

\section{Results and Discussion}

Figure 1 shows the percent correct responses for the activity groups over each of the retention intervals. A repeated measurements analysis of variance on these data indicated that Activities $(F=3.86 ; d f=6 / 63 ; p<.01)$, Retention Interval $(F=8.96 ; d f=4 / 252 ; p<.001)$, and the Activities $\mathrm{x}$ Retention Interval interaction $(\mathrm{F}=\mathbf{2 . 2 5}$; $\mathrm{df}=24 / 252 ; \mathrm{p}<.001$ ) were significant sources of variance. Simple analyses of variance were performed at each of the five retention intervals to determine the locus of the interaction effect. These analyses revealed significant Activity effects at $4 \mathrm{sec}$. $(\mathrm{F}=2.91 ; \mathrm{df}=6 / 63$; $\mathrm{p}<.05), 8$ sec. $(\mathrm{F}=3.14 ; \mathrm{df}=6 / 63 ; \mathrm{p}<.01)$ and $16 \mathrm{sec}$. $(\mathrm{F}=4.83 ; \mathrm{df}=6 / 63 ; \mathrm{p}<.001)$.Scheffé's S-method was applied to the means at each of these intervals and indicated that no pairwise comparisons were significant. From Fig. 1, it appears as if there are essentially two types of curves-the first curve consisting of the 


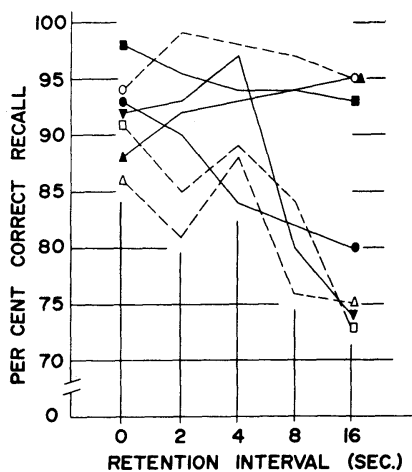

L BLANK

- REHEARSAL

O-- MUSIC

— COLOR NAMING

- COLOR HEARING

DIFFERENT WORD

D-- HEARING

$\triangle--\begin{aligned} & \text { REDUNDANT WORD } \\ & \text { HEARING }\end{aligned}$

Fig. 1. Percent correct recall as a function of retention interval and interval activity.

Rehearsal, Blank, and Music groups which do not change appreciably with the passage of time, and the second curve comprising the performances of the remaining four groups which show the typical retention decrements with increases in retention interval. Consequently, the average performance of the former three groups was compared with the average performance of the latter four groups at 8 and $16 \mathrm{sec}$. Scheffe tests revealed that both contrasts were statistically reliable $(p<.05$ and $<.01$, respectively).

The results of this study indicate that, for retardate Ss, types of retention interval activities can be classified into two distinct categories, namely, those which result in high recall performance and those which show systematic decrements in recall with increasing retention intervals. While there is no way in the present experiment to separate the effects of rehearsal from mere retention of the stimulus, it is clear that no empirical distinction can be made between the memory function obtained under rehearsal instructions and those obtained under retention interval conditions of either no instructions or music listening. The performance of the music listening group reveals that auditory input per se does not necessarily result in retention decrements with increases in the retention interval, but that the decrease is very much dependent upon the type of auditory input used during this interval.

In apparent disagreement with the present findings, Hermelin \& O'Connor (1964) have reported that, under blank retention interval conditions, retardate Ss showed significant declines in the recall of digits with increasing retention intervals whereas normal Ss did not. However, inspection of their data suggests that this decline can be attributed primarily to their younger group of retardate Ss (mean age =12 yr.); their older group of retardate Ss (mean age $=18 \mathrm{yr}$.) showed negligible changes in recall. Since the Ss used in the present study are comparable in age to Hermelin and $O$ 'Connor's older group, the results of the two experiments can be interpreted as being in agreement with each other.

All groups which show a decrease in recall with the passage of time have at least one thing in common: unconnected familar words which differ from the stimulus word are used to fill the retention interval. Hermelin \& O'Connor (1964) also found that familiar word hearing caused significant decrements in the recall of digits between 2 and 6-sec. intervals for retardate Ss. Their data further reveal that this decrement is found only for older Ss, suggesting the presence of an age $\mathbf{x}$ interval activity interaction. Nevertheless, the results of both studies indicate that, for retardate Ss within the age range of 16 to $40 \mathrm{yr}$., auditory input of unconnected familiar materials (either externally presented or self-created) results in similar decreases in single item recall over relatively short periods of time.

\section{Referenees}

Gates, A. I. A reading vocabulary for the primary grades. (Rev. ed.) New York: Teachers College, Columbia University, 1935.

Hermelin, Beate, \& O'Connor, N. Short-term memory in normal and subnormal children. Amer. J. ment. Defic., 1964, 69, 121-125.

Keppel, G. Problems of method in the study of short-term memory. Psychol., Bull., 1965, 63, 1-13.

Postman, L. Short-term memory and incidental learning. In A. W. Melton (Ed.), Categories of human learning. New York: Academic Press, 1964. Pp. 145-201. 